October 2004 - NREL/CP-520-36535

\title{
Growing Pains for New Energy-Saving Technologies
}

\author{
S. Kurtz
}

Prepared for the SPIE Annual Meeting 2004: International Symposium on Optical Science and Technology Denver, Colorado August 2-6, 2004

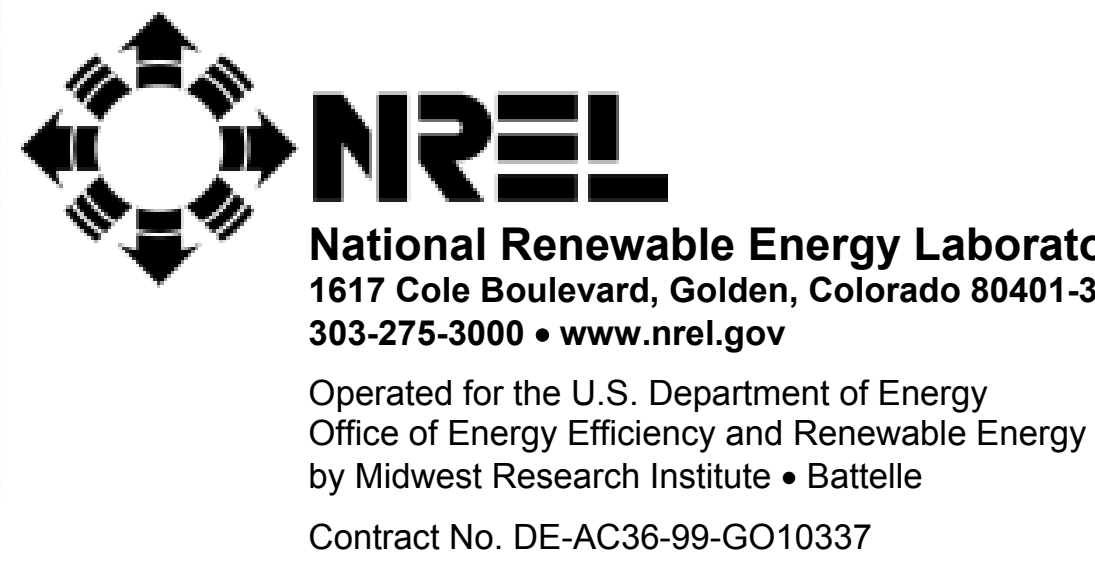




\section{NOTICE}

The submitted manuscript has been offered by an employee of the Midwest Research Institute (MRI), a contractor of the US Government under Contract No. DE-AC36-99G010337. Accordingly, the US Government and MRI retain a nonexclusive royalty-free license to publish or reproduce the published form of this contribution, or allow others to do so, for US Government purposes.

This report was prepared as an account of work sponsored by an agency of the United States government. Neither the United States government nor any agency thereof, nor any of their employees, makes any warranty, express or implied, or assumes any legal liability or responsibility for the accuracy, completeness, or usefulness of any information, apparatus, product, or process disclosed, or represents that its use would not infringe privately owned rights. Reference herein to any specific commercial product, process, or service by trade name, trademark, manufacturer, or otherwise does not necessarily constitute or imply its endorsement, recommendation, or favoring by the United States government or any agency thereof. The views and opinions of authors expressed herein do not necessarily state or reflect those of the United States government or any agency thereof.

Available electronically at http://www.osti.gov/bridge

Available for a processing fee to U.S. Department of Energy and its contractors, in paper, from:

U.S. Department of Energy

Office of Scientific and Technical Information

P.O. Box 62

Oak Ridge, TN 37831-0062

phone: 865.576 .8401

fax: 865.576 .5728

email: mailto:reports@adonis.osti.gov

Available for sale to the public, in paper, from:

U.S. Department of Commerce

National Technical Information Service

5285 Port Royal Road

Springfield, VA 22161

phone: 800.553 .6847

fax: 703.605.6900

email: orders@ntis.fedworld.gov

online ordering: http://www.ntis.gov/ordering.htm 


\title{
Growing pains for new energy-saving technologies
}

\author{
Sarah Kurtz \\ National Renewable Energy Laboratory \\ 1617 Cole Blvd., Golden, CO, 80401 USA
}

\begin{abstract}
As we contemplate a revolution in the lighting industry, it is yet unclear in what form tomorrow's solid-state lighting will emerge. Similarly, photovoltaic (PV) power supplied on a utility scale may take a different form from today's flatplate silicon modules. The success of the PV industry - now a multibillion dollar a year industry and growing at more than $25 \%$ per year - has largely come from integrating solar cells into other products. In many cases, this integration required the formation of new business entities. The solid-state lighting industry faces hurdles that are similar to those faced by the PV industry. Therefore, based on the experiences of the PV industry and others, we predict that the growing pains of the solid-state lighting industry will include: (1) identifying entry markets, (2) integrating light-emitting diodes into attractive products, (3) attaining high reliability for these products, and (4) increasing production of these products, thus lowering costs and opening up new markets. These activities must be implemented, keeping in mind that most consumers do not care about buying "solid-state lighting" and "solar cells." Rather, they want to buy attractive lighting and inexpensive electricity.
\end{abstract}

Keywords: renewable energy, energy efficiency, new technology

\section{INTRODUCTION}

This summer, the newspapers have been full of stories about the higher prices for gasoline. This news has followed reports over the last few years of the increased price of natural gas, the growing U.S. trade deficit driven in large part by imported oil, the prospect of growing imports of natural gas, and the specter of global warming. Concerns about an energy shortage this year are dwarfed only by concerns about terrorism and unrest in the Middle East, which is also the largest source of oil. As the United States and the world debate the best way to provide for a secure future, there is little doubt that an adequate supply of inexpensive energy is a key factor.

As the world's population and standard of living increase, the demand for energy is also increasing. The world's oil fields are still able to meet this demand, but some countries - the United States among them - cannot meet their own needs. Figure 1a shows the increasing gap between the amount of oil consumed and produced by the United States. Dependence on oil from potentially unstable parts of the world is arguably one of the greatest security threats that the United States faces.

To date, North America has been able to produce most of the natural gas required to meet the continent's needs. The deficit from the United States shown in Fig. $1 \mathrm{~b}$ is filled primarily by natural gas imported from Canada. However, the recent rise in natural gas prices has largely been a result of inadequate supply of natural gas in the region. If regional increases in the consumption of natural gas outpace increases in production, the United States may be forced to begin importing liquefied natural gas. If so, over the next years, we could see a rising trade deficit for natural gas, as shown in Fig. 1a for oil.

On a global scale, the finite supply of fossil fuels and the mounting evidence of rising carbon dioxide levels and global warming imply that all countries, not just the United States, should be planning on a changing energy mix in the $21^{\text {st }}$ century. Governments worldwide are working to decrease dependency on oil and natural gas, in general, and on imported oil and natural gas, in particular. Strategies for meeting this challenge include nuclear power plants, cleaner coal-fired power plants with carbon sequestration, renewable energy sources, and reduced consumption of energy. Nuclear power and coal are both abundant sources of electricity, but are outside of the scope of this conference, so will not be discussed further. 
Hydroelectric power is a renewable energy technology that is already widely deployed. Wind power has been used to pump water and do other mechanical work for centuries. More recently, wind power has been successfully deployed for large-scale power generation in Europe, the United States, and elsewhere. The marketplace has seen a steady stream of innovations that can be considered energy-efficient.
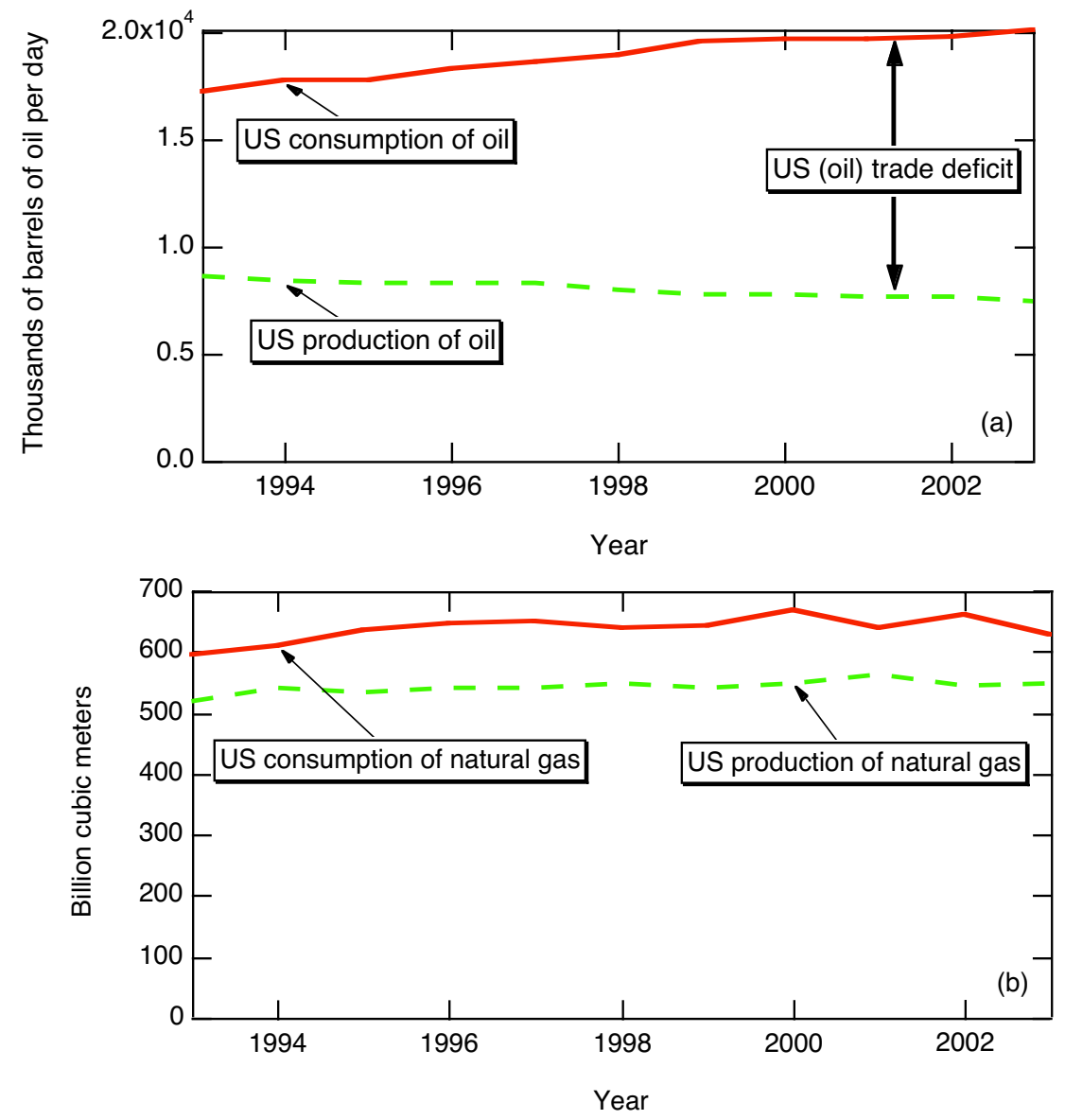

Figure 1. U.S. consumption and production of (a) oil and (b) natural gas. Natural gas has become the preferred technology for many new electricity generating plants because it is clean and easy to use. The relatively weak increase (or decrease) in consumption in recent years is primarily due to a recession in the United States and increased natural gas prices.

This paper focuses primarily on new, energy-efficient lighting technologies and on solar electric technologies. The discussion is not meant to present new technical information, but to relate how the experiences of one industry may be useful to another. I also wish to put forth what may be controversial viewpoints to stimulate discussion and help the industry define new, useful directions. The initial discussion covers entry markets and describes some of the growing pains that the new technologies have experienced — or are likely to experience — as they progress toward the world's goal of saving energy.

\section{IDENTIFYING ENTRY MARKETS}

The solar electric (or photovoltaic) and light-emitting diode (LED) industries have both done very well at identifying and using entry markets for specialty products. Solar cells are now found in many consumer products, including calculators, walk lights, emergency phones, and remote water-pumping stations. Low-power LEDs have been used in consumer electronics for decades. More recently, the advent of high-efficiency LEDs in a rainbow of colors has enabled LEDs to enter new markets, such as traffic signals, cell phones, and automotive applications (both interior, such as dash lights, and exterior, such as tail lights). As successful as these entry markets have been, the end goal for these technologies is not simply consumer markets, but the wider market: large-scale solar electricity generation for PV, and general 
illumination for LEDs. Identifying products and financing schemes applicable to these wider markets has been a more daunting challenge for both technologies.

Certain individuals are always willing to try a new technology, no matter what it looks like. And other people are willing to be significantly inconvenienced - either financially or in terms of personal effort-if they can save energy. These individuals help companies introduce new technologies. Early marketing of compact fluorescent light (CFL) bulbs was successful by identifying consumers interested in conserving electricity. For example, my family heard of an early opportunity to buy CFL bulbs through information provided by the Solar Energy Research Institute. We bought quite a number of these bulbs and discovered that some fit easily into fixtures, whereas others did not (see Fig. 2). I am quite confident that other customers had similar experiences with the bulbs because now when I go to the store, the newer CFL bulbs have more appropriate shapes. In the case of CFL bulbs, these entry markets were effective at helping the industry get product into the market, determining the version of the technology that would appeal to the average consumer, then mass marketing the more mature version of the product.

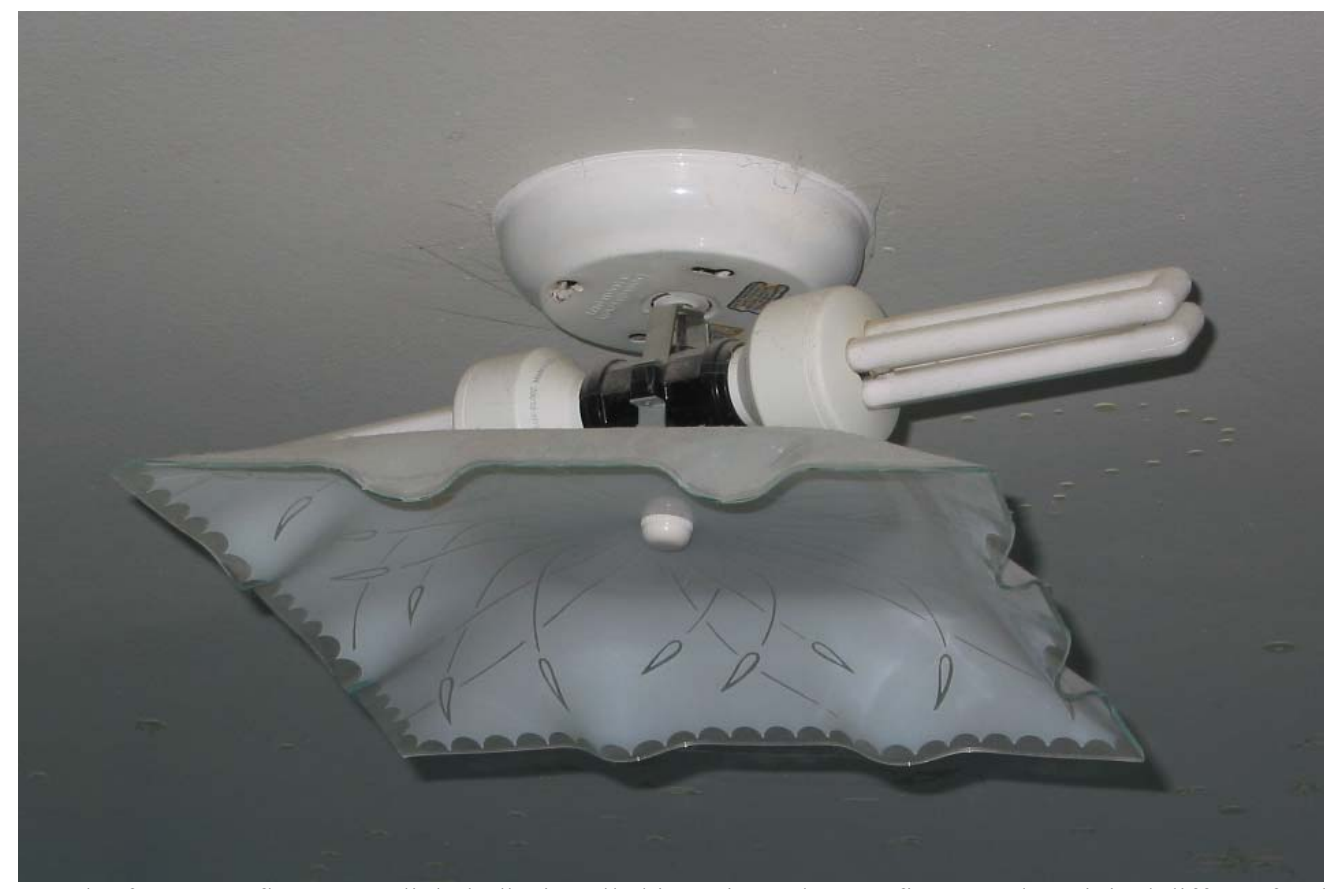

Figure 2. Photograph of compact fluorescent light bulbs installed in an incandescent fixture. The original diffuser for the bulbs was flipped upside down to make room for the longer bulbs. In the inverted configuration, the diffuser is not as attractive, and it is not very effective because the bulbs protrude. This bulb did well in an entry market - appealing to consumers who wanted to conserve energy - and performing very well, but it was not a long-term success. This style of CFL bulb is no longer widely available, most likely for the obvious reason.

Similar to the CFL bulbs, solar technologies have found entry into the wider markets by targeting energy-conscious consumers. Just as these lighting consumers were willing to be creative with CFL bulbs, these solar consumers have helped to evaluate various solar schemes. Solar panels for hot-water heating or for electricity generation are known to be more efficient when mounted at a south-facing tilt. However, the optimal tilt angle does not always match the roof, leading to awkward structures that many people find unappealing on their roof, as shown in Fig. 3. Despite the lack of appeal to the average consumer, these early products provided companies with the opportunity to refine the product, lower costs, and prepare to address larger markets.

\section{DEVELOPING ATTRACTIVE PRODUCTS}

Compact fluorescent lighting and solar electric technologies are both growing out of this awkward phase. Stores now carry CFL bulbs that look almost exactly like the incandescent bulbs used in vanities. These bulbs do not need diffusers and can be interchanged with incandescent bulbs, as shown in Fig. 4. The spiral or loop-type CFL bulbs evolved to a 
smaller size more consistent with most incandescent light fixtures. Similarly, companies have discovered ways to blend solar panels into the roof, as shown in Fig. 5.

LEDs are almost perfectly suited for use in consumer products (see Fig. 6). As a result, the LED industry appears to be able to side-step the awkward market phase described for CFLs and solar panels. I could not find any examples of an LED product that was not appealing in some way. However, as successful as the LED industry has been, it may still encounter an awkward phase as it metamorphoses from an "LED" industry into a "solid-state lighting" industry.

Because the replacement of lighting fixtures occurs over more than a decade, the quickest way for efficient LEDs to reduce electricity consumption is to identify an efficient screw-in bulb to replace incandescent bulbs. However, this approach has two problems: 1) a high-wattage light bulb can be made for pennies, whereas it takes many dollars to manufacture enough LEDs to emit a comparable level of lighting; and 2) creating a replacement bulb ignores the potential of solid-state lighting, while getting snagged on the technological hurdle of handling the waste heat generated by an LED replacement bulb.

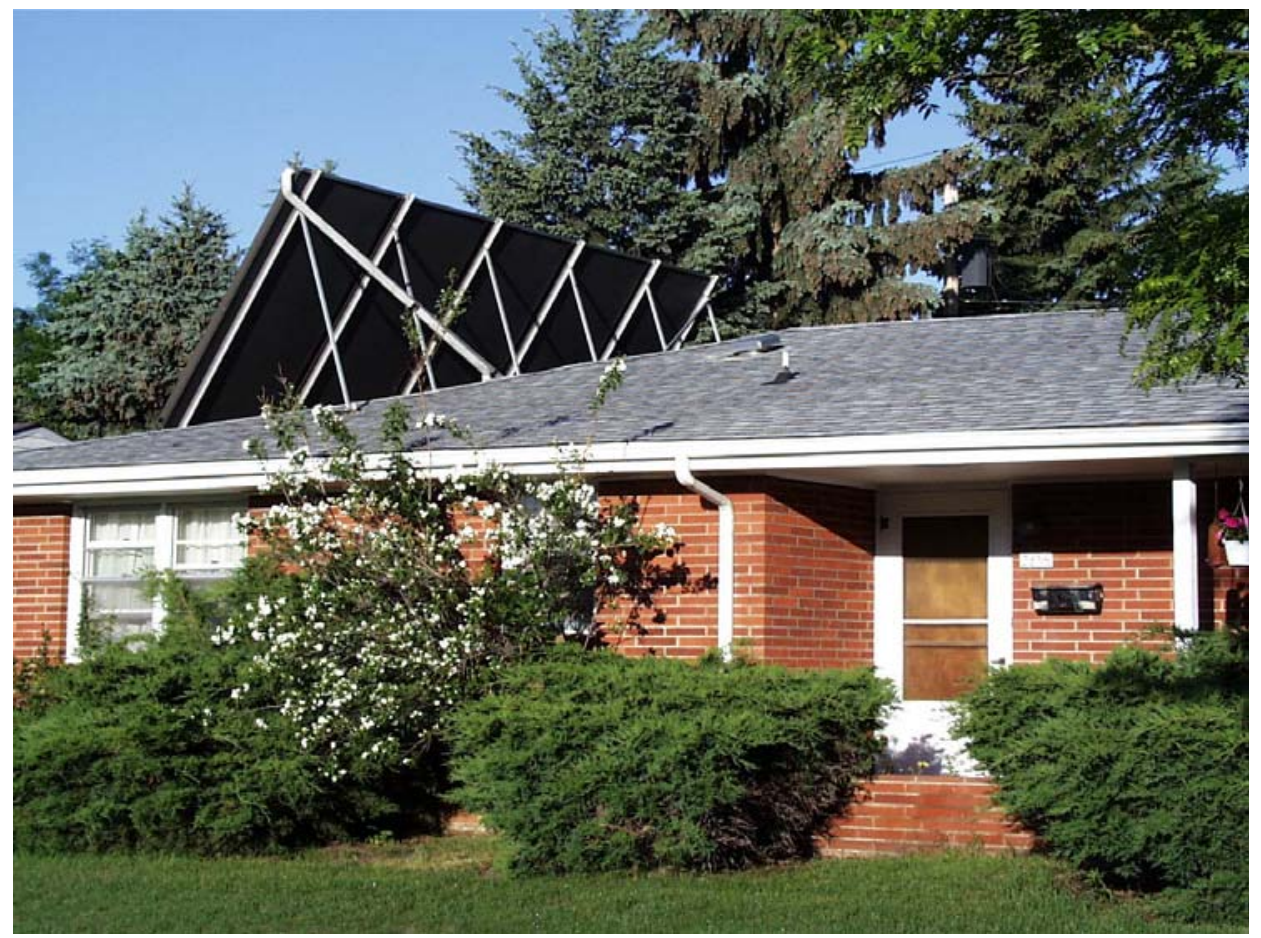

Figure 3. The solar panels on this house may be attractive to this homeowner because of their functionality. But anecdotal evidence shows that such panels are not always considered an asset when it comes time to sell a house. Nevertheless, marketing of products into entry markets such as this provides a very valuable role in the overall development of a technology.

Just as sales of solar panels have increased dramatically when sold as part of a system (e.g., a solar roof), it is likely that sales of solid-state lighting will first be successful when the LEDs are integrated into a lighting fixture. But this may be a challenge. High-brightness LEDs can deliver considerable light in one location. However, attractive general lighting is usually diffuse to minimize glare and must generally cover large areas relatively uniformly. The simple need for more light economically from LEDs has been an ongoing technical hurdle. But choosing the best approach for creating attractive, diffuse lighting is an additional challenge that requires the creativity of an artist, architect, or designer, as much as the skills of an engineer. Companies should be hiring creative staff to work with their engineers to develop solid-state lighting products that explore the possibilities for revolutionizing lighting. The results will be lighting products that look nothing like today's light bulbs, but will distribute light in an attractive way throughout a room, or locally where the light is most needed. A price tag of hundreds of dollars will be viewed as a problem, but many conventional lighting products cost hundreds of dollars. Early sales at high prices will provide the solid-state lighting industry with a pathway to products that will appeal to the average consumer-in both design and price. 


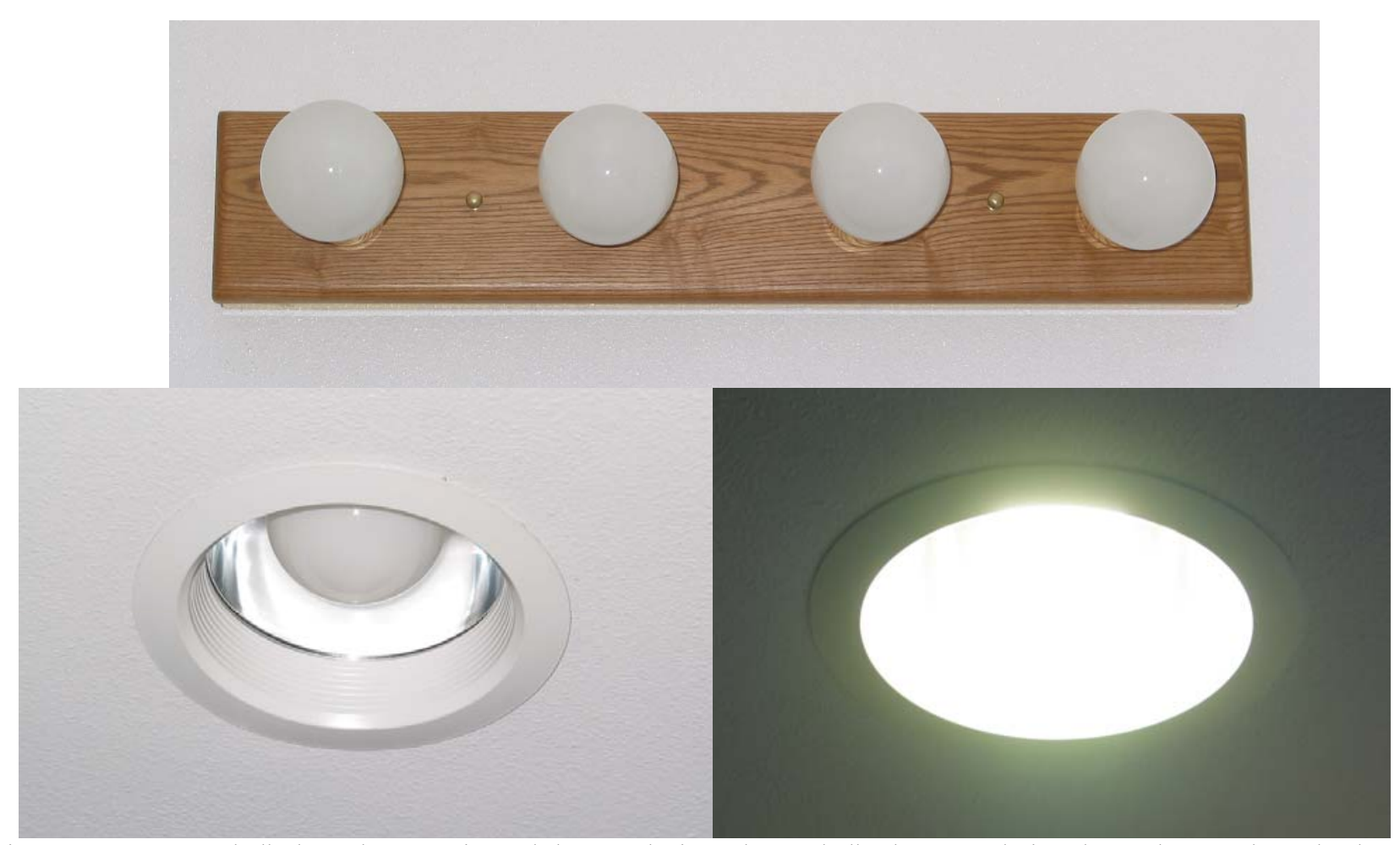

Figure 4. Newer CFL bulbs have the same size and shape as the incandescent bulbs they were designed to replace, as shown by the vanity bulbs in the top photograph. In the lower left photograph, a CFL vanity bulb was placed in a lighting can in the ceiling, providing a light that is attractive (if a can is attractive), as well as efficient. On the lower right, a CFL bulb provides efficient lighting without the awkward protrusion seen in Fig. 2.

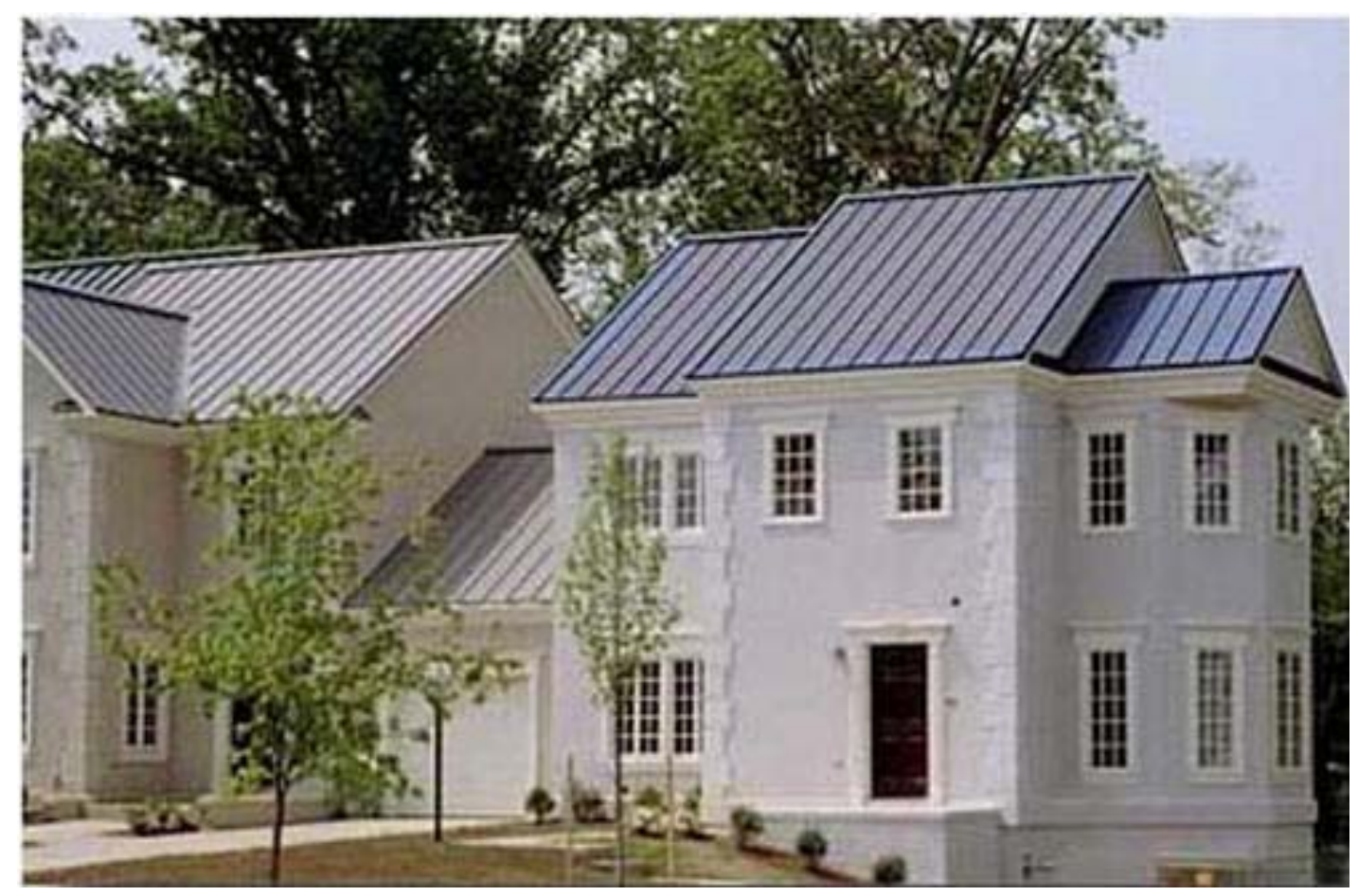

Figure 5. This $1.5-\mathrm{kW}$ solar roof appears almost identical to conventional roofing material. 


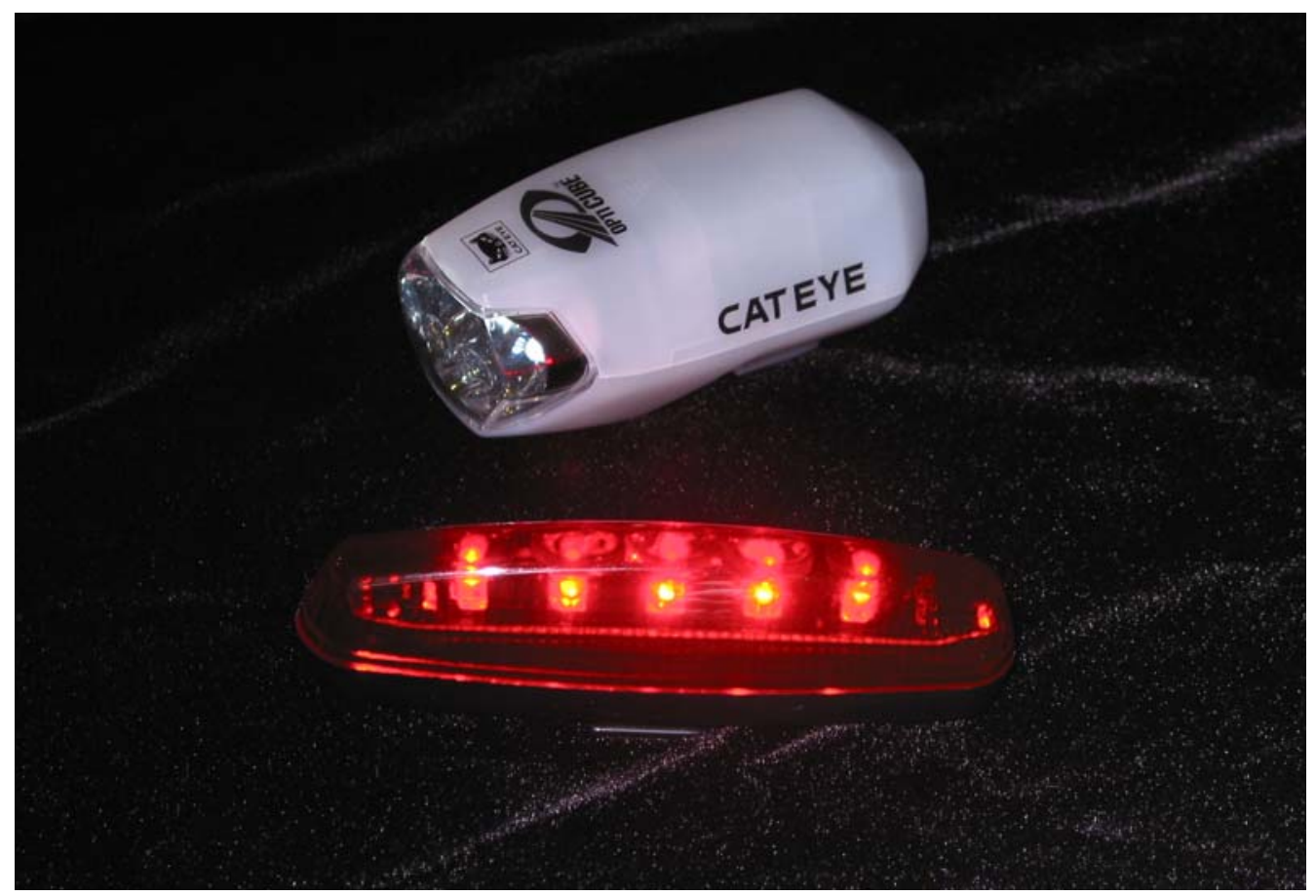

Figure 6. Photo of LED headlight and taillight, made for use on a bike. These are examples of attractive LED applications that have helped to boost sales of LEDs. However, new products must be created to enter the solid-state lighting market. The entry markets for solar cells in consumer products were easier than introducing solar cells into the solar electricity (utility) market. Likewise, identifying entry markets for LEDs in consumer products is easier than identifying the path for entry of solid-state lighting products into the general illumination market.

Forming new partnerships is critical to creating these attractive new products. In the PV industry, PowerLight is one of the most successful American companies. Founded in 1991, PowerLight used a business model that focused on integrating solar panels into building materials and installing them on large buildings. When buying a solar roof, customers benefit by avoiding the cost of the regular roof, and, in some cases, by reducing air-conditioning loads because of the added insulation built into the solar roof. Before PowerLight existed, one could buy solar panels from PV companies and insulation from insulation companies, but few contractors were willing to combine these individual products into a waterproof roof. Selling into a subsidized solar rooftop market in California, PowerLight has grown dramatically and is one of the fastest growing, privately owned PV companies, with offices worldwide.

For the LED industry to move into the solid-state lighting industry, new business entities analogous to PowerLight will likely be required. Currently, we have bulb manufacturers and fixture manufacturers. These manufacturers have a close working relationship to ensure that their products work well together; and they do not want to jeopardize their partnerships by competing with each other. However, what if tomorrow's lighting does not use replacement bulbs at all? Most likely, new lighting products will integrate the LEDs and the optics into a single package. Designing this package will require knowledge of how to mount the LEDs, drive them with appropriate currents, remove the waste heat from the LED, and distribute the light in an attractive manner. Which industry should begin making this revolutionary new lighting? Many new businesses have already been formed. For example, GELcore and Color Kinetics are developing innovative LED lighting products. But, to date, these companies have targeted specialty lighting applications, rather than the general illumination market. Tomorrow's solid-state lighting industry will likely be driven by a mix of new companies and new partnerships formed by existing companies. Based on the PV industry's experiences, we can predict that forming such new business entities will be key to the industry's rapid growth.

While the solid-state lighting industry is developing the vision of tomorrow's lighting products, the solar electric industry is facing a similar question. Currently, flat-plate silicon panels dominate almost every market. But will this be the case in the future? The PV product ideal for rooftops may not be the one best suited for generating utility-scale solar 
electricity. For example, more electricity can be generated from a single PV panel if it is placed on a tracker to follow the movement of the sun. Tracking is inappropriate for rooftop applications, but it may be most appropriate for matching utility load profiles when PV systems are installed in large fields. One necessary growing pain for each of these technologies is a willingness to experiment with many different approaches, realizing and planning that some will fail.

\section{ATTAINING HIGH RELIABILITY}

Everyone agrees that a product must be reliable in the marketplace. But the realities of business and the uncertainty of the performance of some products sometimes result in products that fail in the hands of customers. Past experiences highlight three key steps that help to avoid product failure: 1) developing standards and applying these standards, 2) field testing with "friendly" customers, and 3) remembering to place appropriate weight on reliability considerations when there is pressure to launch a product.

In the 1980s, the PV industry developed a set of standards for both performance metrics and reliability testing. The government supported much of this work, either directly or indirectly. The method developed for reliability testing was as follows: put tested solar panels in the field, observe the failure mechanisms that eluded the original stress tests, then create a new stress test to detect the new failure mechanism. These testing standards have led to PV panels having high reliability.

One failing was that inverters were not included when these standards were developed. And even though today's solar electric systems are widely reported to be highly reliable, inverters do not share this reputation, although they are improving. A second failing of the PV reliability testing was realized with the deployment of new technologies, such as thin-film solar cells made from cadmium telluride. Such cells can show failure mechanisms that differ from those of the silicon panels used to develop the original set of reliability stress tests. Currently, the PV community is developing test methods ${ }^{1}$ for new PV technologies, understanding that the tests that were appropriate for silicon solar panels may not be the best tests for other technologies.

The solid-state lighting community has been diligently working to develop metrics for characterizing white light. Such a standard, which is difficult to develop because it requires understanding the human response, will be critical to industry progress. LED companies have been testing low-power LEDs for many years. But according to the experience of the PV industry and consistent with some reports from LED manufacturers, the new LEDs show a new set of problems and these tests will need to be redeveloped. Government support and partnership with the private sector - both within the United States and with standards organizations around the world - to create and modify standards will speed the creation of this part of the foundation of tomorrow's successful solid-state lighting industry.

Adequate field testing has also been useful to the PV industry. Systems installed without follow-up monitoring are often found years later to have failed. In contrast, working with early customers to arrange for feedback about performance and failures gives companies the information needed to continue to improve products. Limited customer testing may be achieved when manufacturing companies install lighting within their own buildings. However, failure mechanisms typically depend on many circumstances, including local humidity, temperature, and usage patterns. Therefore, complete product testing usually requires testing in a diverse set of geographical and physical environments.

Government support can be useful when new technologies are integrated and monitored in government buildings. Such demonstration projects have often been unpopular, especially when used as a marketing development strategy. However, they can be extremely useful in helping to develop adequate reliability.

Every company intends to launch only products that are reliable. Large companies are usually successful in doing this because they can use profits from an earlier product to finance the development of a new product. But small companies may feel pressure from investors or from their own pocketbooks to introduce a product into the marketplace prematurely. Even if a company proceeds very carefully, there have been times when a product has passed all reliability tests, but still fails in the hands of the customer. When this happens, pertinent information should be shared with other industry members to help avoid recurrence. When one company takes a risk and launches a product that fails, the failure of that product reflects badly on the entire industry. Therefore, a willingness to work together to prevent such failures will greatly facilitate the industry's growth. 


\section{REACHING THE GOAL}

Long-term success of the PV industry could be defined in terms of solar electricity making up at least $10 \%$ of the total electricity generation in the United States by 2030. For the solid-state lighting industry, the U.S. Department of Energy has defined success as reducing electricity consumption by lighting by a factor of two. The success of these two industries in specialty markets is unquestioned, but meeting the broader goals will require products that are both excellent and low priced.

Reducing costs will come with production experience. Specifically, improved manufacturing yield and efficiency, coupled with economies of scale, can dramatically reduce costs over a period of time. Nevertheless, the necessary cost reductions are a major challenge for both the PV and solid-state lighting industries.

The typical customer wants inexpensive electricity and attractive, affordable lighting. Most residential customers assume that the cost of electricity is low enough that they do not need to be concerned whether their lighting is energy efficient. Furthermore, most people today face information overload and do not want to become an expert on lighting technology. As a personal example, last December, I was visiting the home of a friend and commented on her LED Christmas lights. From her response, it was clear that she did not know what I was talking about - that the string of lights she picked out in the store used LEDs, or that they used one-tenth the electricity of a conventional string-she just knew she liked the way they looked.

Similarly, while environmentalists are sometimes excited about a solar electric roof on their house, and some customers are willing to pay extra for a solar electric system that gives them security in the event of a power failure, the typical consumer would prefer to have someone else take care of the solar system. Greater penetration of PV into the electricity generation market will occur when utilities and other energy providers install large PV systems and deliver the electricity to customers in fairly conventional ways. What lighting and electricity customers both want is to be able to simply flip the switch and have the lights turn on.

Ultimately, meeting the aggressive goals defined above requires products that are competitively priced with today's very inexpensive electricity and light bulbs. Cost reduction will occur as manufacturing experience and volume grow, but it is not certain whether costs will be sufficiently lowered to meet the above goals in the next few years.

\section{REDUCING ELECTRICITY CONSUMPTION}

As a final question, we ponder the following: When new renewable energy and energy efficiency technologies are successfully developed and are readily available on a large scale in the marketplace, will their use reduce electricity consumption? If lighting is more efficient, will people simply install more of it and leave the lights burning for more hours?

The goal of private business, which is the foundation of a successful economy, is to make a profit. If a company can convince the public that the company is doing "good things" for the world, or that by buying their product the customer can act in a public spirit, then it may help the company make a profit. With growing concern over energy shortages, pollution, and global warming, companies are increasingly using "green marketing." Nevertheless, the primary goal of such companies is still to make a profit, not to help the environment.

In contrast, the goal of government programs that promote energy efficiency and renewable energy is to reduce our consumption of energy so that the price of electricity can remain low and environmental effects can be reduced. Ironically, the most effective way to persuade people to conserve electricity or to use "green" electricity is for the cost of conventional electricity to increase. The recent rise in natural gas prices reduced the consumption of natural gas by almost $5 \%$ in 2003 relative to 2002 . The industrial and commercial sectors are likely to analyze their costs and make choices that minimize those costs. High electricity costs make the use of energy-efficient technologies imperative. For residential customers, the cost of electricity is currently low enough that they do not focus much on energy efficiency.

In the long run, our success with solid-state lighting and PV may depend on how we define "success." If our goal is to slow global warming by reducing our consumption of fossil fuels, then we are unlikely to be completely successful. However, if our goal is to be prepared in the case of a dire energy shortage, then the crisis itself will help advance us 
toward success. If an energy shortage occurs, the rising price of electricity should sufficiently motivate people to conserve electricity and invest in solar electricity. If, by that time, we have developed the energy-saving technologies, along with a robust distribution infrastructure, then we will have achieved our goal of energy security. Also, when consumers are motivated to choose energy-efficient products, consumer education by the government and industry can be very helpful.

\section{CLOSING THOUGHTS}

As industry and government work together to introduce new energy-saving technologies, they must first focus on achieving the required technological performance and then create new, attractive products (see Table 1). The uniqueness of solid-state lighting makes it very attractive to the consumer, providing an advantage over most new technologies. Designing LEDs for flashing lights and signs has been relatively easy. However, the uncertainty in what the potential "revolution in lighting" will bring is a hurdle that hinders LEDs from moving readily into general lighting applications. To realize this revolution in lighting, the industry must form appropriate partnerships that bring together the needed expertise. The roles of industry and government are complementary - with industry striving to make a profit by selling as many products as possible, while the government strives to see that energy savings actually occur.

Table 1. Some Roles of Industry and Government in Developing and Implementing New Energy-Saving Technologies*

\begin{tabular}{|c|c|}
\hline Industry & Government \\
\hline $\begin{array}{l}\text { Look for new markets and develop new products to meet } \\
\text { their needs. New customers should value something } \\
\text { different about the new technology. }\end{array}$ & $\begin{array}{l}\text { Support the development of standards, by financial } \\
\text { support and coordination efforts, to help build a stable } \\
\text { foundation for a new industry. }\end{array}$ \\
\hline $\begin{array}{l}\text { Plan for many ideas to fail and structure their efforts } \\
\text { accordingly by creating many small business units that } \\
\text { emphasize creativity, have lower costs, and will see early } \\
\text { success defined as entering small markets, with the } \\
\text { possibility of identifying new large markets. }\end{array}$ & $\begin{array}{l}\text { - Plan for some ideas to fail, and support exploration of a } \\
\text { variety of approaches, not choosing winners early on. }\end{array}$ \\
\hline $\begin{array}{l}\text { Match profitable markets and products for industry } \\
\text { success. }\end{array}$ & $\begin{array}{l}\text { - Support the industry's need to form new business } \\
\text { entities. }\end{array}$ \\
\hline $\begin{array}{l}\text { - Market reliable products and reduce costs to achieve com- } \\
\text { petitiveness }\end{array}$ & $\begin{array}{l}\text { Encourage the development of energy-efficient } \\
\text { technologies, as well as products that can replace } \\
\text { inefficient old technology. Help educate the public } \\
\text { about these benefits. }\end{array}$ \\
\hline
\end{tabular}

*Some of the ideas presented here and elsewhere in this paper were taken from reference 2.

Once a new energy-saving technology is developed, higher energy costs are likely to be the most effective way to speed widespread deployment. Ironically, avoiding high energy costs was the goal! But there is no need to be dismayed about this situation. If we are pursuing energy security without regard to cost, then we are guaranteed success. Sunlight delivers many times more energy than we need, and the technology exists to convert this sunlight into electricity. The challenge is to use the solar energy in a cost-effective manner.

The solid-sate lighting and PV industries must move into the markets of general illumination and large-scale electricity generation. In doing so, they will transition through the stages of developing technology, identifying entry markets, developing attractive and reliable products, and, finally, increasing production volume and reducing costs. Eventually, all the growing pains will be a thing of the past. And the final, successful products will be those that deliver exactly what customers want—-the ability to simply "flip a switch" and have the lights turn on.

\section{ACKNOWLEDGMENTS}

I wish to thank Craig Christensen for the photo in Fig. 3, and D. Gwinner, T. Surek, T. Coutts, and R. McConnell for useful comments on the manuscript. This work was supported by the U.S. Department of Energy under Contract No. DE-AC36-99GO10337. 


\section{REFERENCES}

1. McConnell, R., L. Ji, J. Lasich, and R. Mansfield, "Concentrator photovoltaic (PV) qualification standards for systems using refractive and reflective optics." $19^{\text {th }}$ European Photovoltaic Solar Energy Conference 2004 (in press).

2. Christensen, C. M., The Innovator's Dilemma, When new technologies cause great firms to fail, Harvard Business School Press, Boston, Massachusetts 1997. 


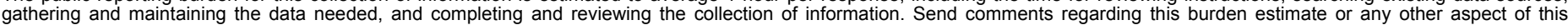

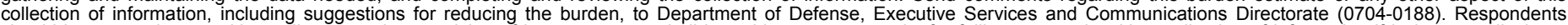

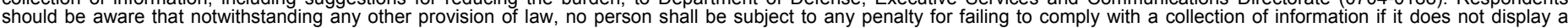

should be aware that notwithstanding

PLEASE DO NOT RETURN YOUR FORM TO THE ABOVE ORGANIZATION.

\begin{tabular}{|c|c|}
\hline $\begin{array}{l}\text { 1. REPORT DATE (DD-MM-YYYY) } \\
\text { October } 2004\end{array}$ & 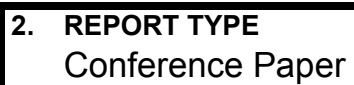 \\
\hline
\end{tabular}

Growing Pains for New Energy-Saving Technologies

3. DATES COVERED (From - To)

2-6 August 2004

5a. CONTRACT NUMBER

DE-AC36-99-G010337

5b. GRANT NUMBER

5c. PROGRAM ELEMENT NUMBER

5d. PROJECT NUMBER

NREL/CP-520-36535

5e. TASK NUMBER

52001000

5f. WORK UNIT NUMBER

7. PERFORMING ORGANIZATION NAME(S) AND ADDRESS(ES)

National Renewable Energy Laboratory

1617 Cole Blvd.

Golden, CO 80401-3393

9. SPONSORING/MONITORING AGENCY NAME(S) AND ADDRESS(ES)

\section{PERFORMING ORGANIZATION REPORT NUMBER}

NREL/CP-520-36535

10. SPONSOR/MONITOR'S ACRONYM(S) NREL

11. SPONSORING/MONITORING AGENCY REPORT NUMBER

\section{DISTRIBUTION AVAILABILITY STATEMENT}

National Technical Information Service

U.S. Department of Commerce

5285 Port Royal Road

Springfield, VA 22161

13. SUPPLEMENTARY NOTES

14. ABSTRACT (Maximum 200 Words)

As we contemplate a revolution in the lighting industry, it is yet unclear in what form tomorrow's solid-state lighting will emerge. Similarly, photovoltaic (PV) power supplied on a utility scale may take a different form from today's flatplate silicon modules. The success of the PV industry-now a multibillion dollar a year industry and growing at more than $25 \%$ per year-has largely come from integrating solar cells into other products. In many cases, this integration required the formation of new business entities. The solid-state lighting industry faces hurdles that are similar to those faced by the PV industry. Therefore, based on the experiences of the PV industry and others, we predict that the growing pains of the solid-state lighting industry will include: (1) identifying entry markets, (2) integrating lightemitting diodes into attractive products, (3) attaining high reliability for these products, and (4) increasing production of these products, thus lowering costs and opening up new markets. These activities must be implemented, keeping in mind that most consumers do not care about buying "solid-state lighting" and "solar cells." Rather, they want to buy attractive lighting and inexpensive electricity.

15. SUBJECT TERMS

PV; renewable energy; energy efficiency; new technology;

\begin{tabular}{l} 
16. SECURITY CLASSIFICATION OF: \\
\begin{tabular}{|l|l|l|}
\hline $\begin{array}{l}\text { a. REPORT } \\
\text { Unclassified }\end{array}$ & b. ABSTRACT & c. THIS PAGE \\
& Unclassified & Unclassified \\
\hline
\end{tabular} \\
\hline
\end{tabular}

19a. NAME OF RESPONSIBLE PERSON

19b. TELEPONE NUMBER (Include area code) 